International Journal of Life Sciences
Available online at www.sciencescholar.us
Vol. 4 No. 1, April 2020, pages: 8-18
e-ISSN: 2550-6986, p-ISSN: 2550-6994
https://doi.org/10.29332/ijls.v4n1.385

\title{
Institutional Development of Coconut Agribusiness in North Sulawesi Province
}

\author{
(D) corsanat \\ Stella Maria Pingkan Paendong a, Made Antara ${ }^{b}$, Ketut Budi Susrusa c , I Ketut Suamba d \\ Manuscript submitted: 18 November 2019 Manuscript revised: 27 December 2019, Accepted for publication: 28 January 2020
}

Corresponding Author ${ }^{\text {a }}$

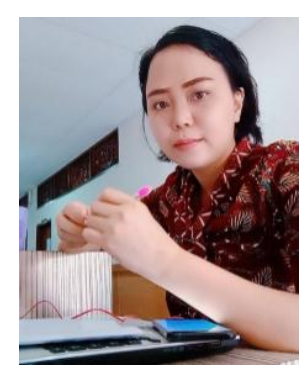

Keywords

institutional;

agribusiness;

coconut;

ISM;

saler;

\begin{abstract}
The purpose of this study is to identify the conditions and institutional role of coconut agribusiness in North Sulawesi; formulate a strategy model for institutional development of coconut agribusiness in North Sulawesi Province. The study was conducted in the highest coconut producing area in North Sulawesi with qualitative methods supported by quantitative data through the use of Structural Conduct Performance (SCP) analysis and Interpretative Structural Modeling analysis. The technique for determining informants is purposive sampling. The grand theory in this research is institutional theory and agribusiness theory. The coconut agribusiness institution in North Sulawesi identified several types that play a role, namely: farmer groups, transportation businesses, universities, banks, cooperatives, field extension workers (ppl), collectors, middlemen, industries, wholesalers and village regulations. Strategies and programs for developing coconut agribusiness institutions in North Sulawesi that refer to the role of tertiary institutions as key sub-elements of the institutional elements involved: a. Training for farmers and institutions involved in coconut agribusiness; $b$. Provision of experts in running a coconut agribusiness business unit; c. Assistance in each coconut agribusiness business unit.
\end{abstract}

International Journal of Life Sciences (C) 2020.

This is an open access article under the CC BY-NC-ND license (https://creativecommons.org/licenses/by-nc-nd/4.0/).

\section{Contents}

Abstract

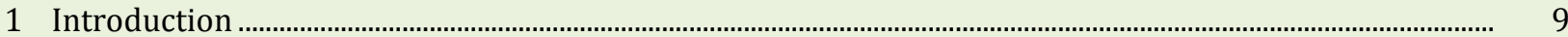

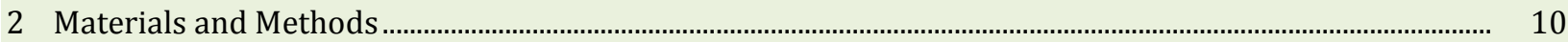

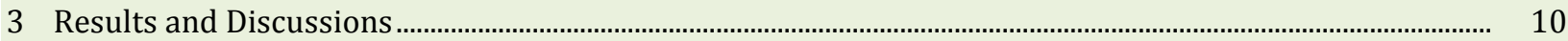

3.1 Institutional condition of coconut agribusiness in North Sulawesi .............................................................. 10

\footnotetext{
a Udayana University, Denpasar, Indonesia

b Udayana University, Denpasar, Indonesia

c Udayana University, Denpasar, Indonesia

d Udayana University, Denpasar, Indonesia
} 
4 Conclusion

Acknowledgments..

References

\section{Introduction}

North Sulawesi Province is an agrarian area where most people's lives depend on the agricultural sector. Some potential areas such as plantations (coconut, cloves, nutmeg, coffee, and vanilla), agriculture, fisheries, and marine are the main capital of North Sulawesi to develop and enhance its economic growth. Coconut itself already has derived derivative products such as coconut oil, activated carbon, coconut fiber, and other products that provide economic added value. Coconut commodities are dominated by smallholder plantations whose land is not too broad and the level of productivity is lower than management by large plantations.

Coconut commodities in North Sulawesi have the third largest area of coconut after East Java and Riau, so looking at the source of raw materials for the coconut derivative industry in North Sulawesi, their derivative products can still be developed. Several coconut-based industries have existed in Bitung City, namely industries that produce coconut oil, coconut shells, copra, shell charcoal, activated carbon, coconut fiber and virgin coconut oil (VCO), nata de coco. Two reasons support for the commodity to be processed into derivative products so that it has added value. First, the primary agricultural sector (coconut commodity) has a low elasticity of demand for income. This is indicated by the relatively resilient performance of the growth of the agricultural sector during the crisis, but when the economic situation improved and people's incomes increased demand for agricultural commodities did not increase by the same proportion. Unlike the case with the demand for manufactured products, which are very elastic to increasing income. Second, the non-oil processing industry sector has the potential to create added value, encourage the development of other sectors and create jobs.

Until now the lack of role and involvement, especially institutional oversight in supporting the activities of coconut farmers in North Sulawesi, still needs to be improved. Coconut farmers are still operating on their own, the expected institutional facilities can increase coconut productivity which is also a mainstay product in North Sulawesi. The current condition of palm oil in North Sulawesi encourages researchers to see institutional empowerment in coconut agribusiness in supporting institutional economic development in North Sulawesi.

Institutional economic development, especially in marketing coconut commodities, still needs to be developed further, both to strengthen the people's economy, and as a mainstay of Indonesia in supporting free trade as a sector of the people's economy. Although most people and even economists are still happy to return to their quantitative equations, the quantitative biases in economics and economic development over the past decade have been more favorable for resource allocation analysis issues, such as planning and forecasts than for implementation issues, which indeed cannot be quantified. Many decision-makers are aware of the important role of institutions in development strategies.

Institutional economics tries to find a way out of the stagnation or weakness of the approaches to agricultural development that have been implemented by the government. Experience shows that a critical and critical analysis of the problem to be overcome is needed. The problems faced by coconut farming show that variations in sources of interdependence require institutions that are appropriate to the character of each situation. However, it can be stated generally that the institution or organization is very important in agricultural development, especially in the welfare of farmers (Pakpahan, 2012).

This research is related to the development of coconut agribusiness institutions in North Sulawesi. Institutions or organizations are very important in agricultural development, especially in the welfare of farmers. The institution is a rule that refers to an organization that has the function, role, involvement required by the actors in this case by rural communities to create good services, especially to stimulate the rural economy. North Sulawesi Province is an agrarian area with the majority of people's lives being the largest coconut producer in Indonesia. Thus a stable coconut agribusiness institution will support increased production of high coconut plantations and will increase farmers' income and welfare.

Paendong, S. M. P., Antara, M., Susrusa, K. B., \& Suamba, I. K. (2020). Institutional development of coconut agribusiness in North Sulawesi Province. International Journal of Life Sciences, 4(1), 8-18. https://doi.org/10.29332/ijls.v4n1.385 


\section{Materials and Methods}

The research on the institutional development of coconut agribusiness in North Sulawesi is designed on the type of qualitative research method which in principle is a study that produces written data from the interviewee and the behavior of people observed naturally to be interpreted. In a qualitative method, the type of research chosen is a case study. Case studies are research that seeks to explore a problem with clear boundaries, in-depth data accompanied by a variety of accurate information (Mujahidin, 2014; Parraga et al., 2017). This research was carried out in North Sulawesi Province. The research location was chosen purposively based on the consideration that this location is one of the largest coconut producing regions in Indonesia. The research location has an eastern boundary with the Republic of the Philippines, an eastern border with the Maluku Sea, a western boundary with Gorontalo Province and a southern boundary with Tomini Bay. This research was conducted in a period of 1 year starting from October 2017 to October 2018.

Determination of research respondents was every regency and city with the highest area of coconut plantation, namely South Minahasa Regency: Tenga District, Amurang Barat District, Sinonsayang District, North Minahasa District: Airmadidi District, Dimembe District, Kauditan District, Talaud Islands District: Kalongan District, District of Tampan "Amma, District of Kabaruan. and the North Sulawesi Provincial Plantation Office, North Sulawesi Province Cooperative and UMKM Office, North Sulawesi Province Industry and Trade Office, North Sulawesi Province Agricultural Training and Counseling Office. The instruments used in this study are (1) A list of questions or structured questionnaire that is designed so that it is valid to measure the parameters that actually want to be measured. (2) An interview guide that only includes the main questions. This guide is used when collecting data through in-depth interviews and focus group meetings. (3) Photographic equipment in the form of a camera for the purpose of visualization, data documentation, and processing of other related information. Data analysis in this study includes; descriptive analysis whose aim is to explain the characteristics of coconut institutions in North Sulawesi, followed by ISM analysis to obtain the formulation of institutional strengthening programs on coconut agribusiness in North Sulawesi. from Interpretative Structural Modeling Analysis.

\section{Results and Discussions}

\subsection{Institutional condition of coconut agribusiness in North Sulawesi}

The coconut institutionalization in North Sulawesi province based on the results obtained was then analyzed descriptively by linking it with agribusiness theory starting from the procurement company subsystem and distribution of production facilities, farming production subsystems, production processing subsystems (agroindustry), output marketing companies subsystems and supporting services subsystems itself. Subsystems for the procurement and distribution of production facilities, there are institutions that play a role in banking and village regulations. Subsystems of farming production companies, the institutions in them are farmer groups, banks, collectors, middlemen. Production processing subsystems (agroindustry), institutions that play a role are universities, PPL extension agents, banking, large traders and industry. The results marketing company subsystem has an institution that plays a role in it is the transportation and cooperative business.

Maximizing the existing institutional work in the development of coconut agribusiness institutions in North Sulawesi, which is of particular concern is that universities are increasingly expected to have a role to be involved in coconut agribusiness in North Sulawesi. Higher education is found in the yield processing subsystem (agro-industry). The findings of scientists who are in higher education would be able to devote their knowledge to coconut agribusiness in North Sulawesi.

The next level of concern is; farmer groups, transportation businesses, cooperatives, collectors, middlemen, industries, large traders. Connected with agribusiness, they are related to farming production company subsystem, yield marketing company subsystem, yield processing company subsystem. At the next level of concern is the institutional extension officer (PPL). Connected with agribusiness, they are related to the results processing subsystem. The last level is the one that concerns the institutional regulations of the 
village and banking. Connected with agribusiness, which is related to the subsystem of the company channeling production facilities.

\subsection{Strategic development strategy for coconut agribusiness in North Sulawesi}

In formulating strategies and programs, the use of the interpretative structural modeling (ISM) method is very useful, because in the model the hierarchy of institutional agribusiness institutional development in North Sulawesi has been explained in a structured manner. Each element that is composed of several sub-elements in this discussion will be described one by one. For more details, the key elements in each of the elements in the development of coconut agribusiness institutions in North Sulawesi are described in Table 1.

Table 1

Key elements of institutional development of coconut agribusiness in North Sulawesi

\begin{tabular}{|c|c|c|c|}
\hline Number & Element & Key Element & Code \\
\hline 1 & $\begin{array}{l}\text { Program } \\
\text { Objectives }\end{array}$ & $\begin{array}{l}\text { A vehicle for cooperation; Educational } \\
\text { vehicle; Accommodate and channel the } \\
\text { aspirations of farmers; Commercial activities } \\
\text { and organization of agricultural resources; } \\
\text { Defending collective interests }\end{array}$ & E1,E2,E3,E5,E7 \\
\hline 2 & $\begin{array}{l}\text { Program } \\
\text { requirements }\end{array}$ & Business processing unit & E3 \\
\hline 3 & $\begin{array}{l}\text { Affected } \\
\text { Community } \\
\text { Sector }\end{array}$ & $\begin{array}{l}\text { Communities involved in the company: } \\
\text { procurement of distribution facilities; farm } \\
\text { production; the processing of products } \\
\text { (agro-industry); marketing results; } \\
\text { supporting services }\end{array}$ & $\mathrm{E} 1, \mathrm{E} 2, \mathrm{E} 3, \mathrm{E} 4$ \\
\hline 4 & $\begin{array}{l}\text { Institutional } \\
\text { system program } \\
\text { constraints }\end{array}$ & Buyer; Businessmen & E1, E2 \\
\hline 5 & Possible changes & $\begin{array}{l}\text { The increasing synergy between institutions; } \\
\text { Farmer institutional empowerment; } \\
\text { Information development and } \\
\text { dissemination; Increased support for } \\
\text { facilities and infrastructure. }\end{array}$ & E1, E2, E3, E4 \\
\hline 6 & $\begin{array}{l}\text { Institution } \\
\text { involved }\end{array}$ & College & E3 \\
\hline
\end{tabular}

Academics have the role to provide new knowledge resulting from research and development activities. The knowledge produced by academics becomes information for other involved institutions. This information is used by farmer groups, transport businesses, banks, cooperatives, PPL, collectors, middlemen, industries, big traders to the formation of village regulations in the framework of developing the coconut agribusiness institutions in North Sulawesi.

Based on the results of interpretive structural modeling analysis of key elements, strategies for developing institutional development of coconut agribusiness in North Sulawesi can be prepared. From the results of the analysis of the six elements using the interpretative structural modeling method, six strategies were developed in the development of coconut agribusiness institutions in North Sulawesi.

Paendong, S. M. P., Antara, M., Susrusa, K. B., \& Suamba, I. K. (2020). Institutional development of coconut agribusiness in North Sulawesi Province. International Journal of Life Sciences, 4(1), 8-18. https://doi.org/10.29332/ijls.v4n1.385 
1) Optimize the development of institutional functions as a vehicle for cooperation, a vehicle for education and channeling the aspirations of farmers.

The development of coconut agribusiness institutions in North Sulawesi Province is associated with the results of the Interpretative Structural Modeling analysis, the purpose of development is to optimize the development of institutional functions as a vehicle for cooperation, a vehicle for education and channeling the aspirations of farmers. This strategy emphasizes optimizing the existing institutional functions and those directly related to the coconut agribusiness process in North Sulawesi.

Institutional development by optimizing the functions of existing institutions but not yet carrying out the tasks as they should. This relates to what Rachbini (2002), described, the existing institutions may not develop because they are hampered by feudalism and collusion, corruption, nepotism which become the institutional values attached to individuals. Based on the strategy of optimizing the development of institutional functions as a vehicle for cooperation, a vehicle for education and channeling the aspirations of farmers, programs are formulated as follows:

a) Building networks and cooperation between institutions

Building networks and cooperation between institutions is very important in realizing the development of coconut agribusiness institutions in North Sulawesi. Collaboration between institutions can complement the shortcomings in the existing needs for prosperity with the farming community and the sustainability of the coconut agribusiness institutions in North Sulawesi. The form of network building and cooperation activities in the development of coconut agribusiness institutions in North Sulawesi at this time needs to be carried out, namely establishing a coconut commodity market managed by institutions related to it in realizing the development of coconut agribusiness institutions in North Sulawesi. Even though it is still in process but if there is a commitment then everything will be realized.

b) Provision of social facilities for living together

The provision of social facilities for living together is one of the strategies to realize the goals of developing the coconut agribusiness institution in North Sulawesi. To realize the right institution, it can play a role in realizing the welfare of the coconut farmer's community in North Sulawesi. The desire to be better can be expressed in the provision of social facilities for living together. Socially motivated factors can encourage cooperation in the development of existing institutions such as social assistance, socialization to the community so that together they can realize what their common goal is.

c) Increasing formal and no formal education for farmers who support the coconut business sector When we enter community life and our institutions begin to make an impact, from there we will see what they need. As a vehicle for cooperation and a vehicle for education relating to the community, especially coconut farmers, assistance in formal and non-formal education for farmers who support the coconut business sector. Activities that are realized such as training to make products derived from coconuts. Train the skills of coconut farmers to increase income, the welfare of the coconut farmers in North Sulawesi.

2) Increasing the coconut processing business

The need for programs on the development of coconut agribusiness institutions in North Sulawesi that are more needed or that should be highlighted is on increasing the coconut processing business. The purpose of coconut processing is to increase added value (Saragih, 2010). Efforts to increase the added value of primary agricultural products are the basis of developing the concept of agro-industry.

a) Provision of institutional facilities and infrastructure

The reluctance of farmers to buy modern equipment is still so great that it is unlikely that substantial modernization in Indonesia will occur (Krisnamurthi et al., 2010). The same must be done by the existing institutions in dealing with problems that occur in coconut farming in North Sulawesi to progress. The provision of facilities and infrastructure, especially in the coconut processing business units in Sulawesi, is the main thing in supporting the development of coconut farming in North Sulawesi.

b) Provides learning resources

The institutional challenges involved in the delivery of agricultural innovations going forward are being able to develop agricultural innovations that are effective, participatory and sustainable (Indraningsih, 2016; Ginaya et al., 2019). Likewise in increasing the coconut processing business which is an element 
of program needs in the development of coconut agribusiness institutions in North Sulawesi, it can provide learning resources by related institutions for the needs and interests of farmers.

c) Providing information needed

Pricing information based only on word of mouth from each person who works as an intermediary trader. One of the principles of development through the development of the agribusiness paradigm is the support of information systems. Data availability is accurate and easy to obtain when needed. The data can be in the form of price information. Efforts to develop coconut agribusiness institutions in North Sulawesi in the elements of program needs, the main strategy of which is increasing coconut processing business, specifically programs that can be carried out by related institutions are to provide the information needed for farmers' needs and interests.

3) Increasing the role of the community in all sectors of coconut agribusiness

In the third element is the community affected by the main sub-elements are all sectors of coconut agribusiness ranging from upstream to downstream influence each other. Form a strategy to increase the role of the community in all sectors of coconut agribusiness. With several existing programs, namely: Increasing the competence of coconut farmers; The joint development of farmer groups in production service procurement business unit, processing services business unit, marketing service business unit, capital business unit; Business capital awards to all coconut agribusiness communities. The agribusiness paradigm is a model that includes systems of pre and cultivation, harvest, postharvest and marketing activities and their supporting sectors as a system that is strongly integrated and difficult to separate (Saragih, 2010).

a) Improving the competence of coconut farmers.

Competence can be increased through education both long-term education and short-term education such as training (Indraningsih, 2016). This happens because the coconut farming community still needs to add knowledge related to the world of coconut farming to further enhance their needs. Efforts to develop coconut agribusiness institutions in Sulawesi in the North in the third element of society in all sectors of coconut agribusiness, the program to improve the competency of coconut farmers community carried out by the relevant institutions is to provide education, training needed for the needs and interests of the farmers.

b) The joint development of farmer groups in business units supplying production facilities; processing services business unit; marketing services business unit; capital business unit

Gapoktan capacity building is intended to be able to function as a farming unit, processing business unit, production facility and infrastructure business unit, marketing business unit and microfinance business unit and other supporting service units so that it becomes a strong and independent farmer organization (Minister of Agriculture Regulation SK-273 /Kpts/OT.160/4/2007). Efforts to develop a coconut agribusiness institution in Sulawesi in the North in the third element of the community in all sectors of the coconut agribusiness, which are joint farmer group development programs in business units providing production facilities; processing services business unit; marketing services business unit; the capital business unit carried out by the relevant institution is to foster and develop business partners, which are needed for the needs and interests of the peasant community.

c) Business capital awards to all coconut agribusiness communities

Institutional economics focuses on assessing institutional variables such as jurisdictional boundaries, property rights and representation rules which are grouped into two categories: analysis of the impact of institutional change and analysis of institutional development (Schmid, 1987). Efforts to develop the coconut agribusiness institution in Sulawesi in the North in the third element of the community in all sectors of the coconut agribusiness, where the business capital award program for all coconut agribusiness communities is carried out by the relevant institutions is to analyze the impact of institutional changes, as a basis for rewarding the business capital needed to the needs and interests of coconut farmers in North Sulawesi.

4) Increasing business actors in the development of coconut agribusiness

The value or norm used as encouragement in the formation of the farmer association is that the fate of a people will not change except by the people themselves. With this consideration, the idea was built to form

Paendong, S. M. P., Antara, M., Susrusa, K. B., \& Suamba, I. K. (2020). Institutional development of coconut agribusiness in North Sulawesi Province. International Journal of Life Sciences, 4(1), 8-18. https://doi.org/10.29332/ijls.v4n1.385 
an association whose main actors were the government, coconut plantation farmers with existing institutional support (Pakpahan, 2012).

The fourth element is the constraints of the institutional system program. The main strategy is to increase business actors in the development of coconut agribusiness. Form several existing programs namely: Building a network; Setting the marketing process; Involving institutions in the form of governance.

a) Build a network

One of the roles of agricultural extension is to develop farmer institutions. Developing the institutional capacity of farmers is the task of the government through agricultural extension institutions (Anantanyu, 2011). Efforts to develop coconut agribusiness institutions in North Sulawesi in the four elements of the program constraints, which become a network building program carried out by the relevant institutions are to develop institutions and activity forums for the main actors and business actors and facilitate those needed for the needs and interests of the coconut farmers in North Sulawesi.

b) Setting the marketing process

The problem often faced by coconut farmers in running their businesses is marketing collateral. Partnerships between farmers and other business actors can improve marketing efficiency to help farmers get a fair selling price and guarantee that the products can be absorbed by the market. Efforts to develop coconut agribusiness institutions in North Sulawesi in the four elements of the program constraints, which become the marketing process regulation program carried out by the relevant institutions are to consider distribution, market chains, product quality, and other related factors ranging from the products produced to consumer's hands.

c. Involving institutions in the form of governance

The dilemmatic condition usually arises from extension institutions because of biased interests. Agricultural extension workers, both government and private employees, are members of staff of the institutions that assign them so that it is not uncommon to do their work more oriented to the interests of the service than to the interests of farmers. Efforts to develop coconut agribusiness institutions in North Sulawesi in the four elements of the program constraints, which become programs involving institutions in the form of regulatory procedures, are strengthening the institutional capacity of farmers who require commitment to institutions to carry out their duties properly for the needs and interests of the coconut farmers in North Sulawesi.

5) Increasing the synergy of institutional functions

In the fifth element is a change that is possible. Form a strategy to improve the synergy of institutional functions. With several existing programs namely: increasing mastery of managerial principles at the coconut agribusiness institutions; increasing cooperation between institutions in coconut agribusiness, providing learning resources including information needed.

Farmer institutions are formed have several roles, namely: tasks in the organization to mediate between the state and society; tasks as resources include mobilization of local resources (labor, capital, material, information) and their management in achieving community goals, service tasks, tasks between organizations (Uphoff, 1989).

a) Increased mastery of managerial principles in coconut agribusiness institutions

Institutional management is a process of collaborating through other people or other resources, with a structure and pattern of relations between communities or organizations that are binding to each other so that relationships between humans or organizations are formed in a container in which there are boundary factors and have a common goal. Efforts to develop coconut agribusiness institutions in North Sulawesi in elements of five possible changes, the program to improve the mastery of managerial principles at the coconut agribusiness institutions carried out efficient utilization of resources by related institutions is to analyze resource management, production factors, and production processes, to the processing of results. The impact of institutional changes, as a basis the business needed for the needs and interests of the coconut farmers in North Sulawesi.

b) Increasing cooperation between institutions in coconut agribusiness

Farmer organizations consisting of a group of farmers who grow based on familiarity and harmony and common interests in utilizing agricultural resources to work together to improve the productivity and welfare of their members. Efforts to develop coconut agribusiness institutions in North Sulawesi in 
elements of five possible changes, the program of increasing cooperation between existing institutions in coconut agribusiness carried out through a conducive climate, as well as mutual trust, mutual support for the needs and interests of the coconut farmers in North Sulawesi.

c) Provide learning resources including the information needed

An organization is a complete container and is authorized by a legal body that gets the public mandate to carry out its duties. An organization consists of elements of shared goals, structure, technology and participants which all elements interact dynamically with each other in the environment and situations of risk and uncertainty (Pakpahan, 2012). Efforts to develop coconut agribusiness institutions in North Sulawesi in elements of five possible changes, the program provides learning resources including information needed to improve institutional synergy such as the publication of print and electronic media for the information needs of coconut farmers in North Sulawesi.

6) Increasing the role of educational institutions in developing coconut agribusiness.

The sixth element is the institution involved. Form a strategy to increase the role of educational institutions in developing coconut agribusiness. With several existing programs, namely: Training for coconut farmers and institutions involved in coconut agribusiness; Training for coconut farmers involved in coconut agribusiness; Assistance in each coconut agribusiness business unit. The availability of technology and technology experts is the responsibility of the government. Therefore there is a need for policies that provide opportunities and the role of research institutions as technology producers and extension institutions as innovators and technology motivators (Damanik, 2015). As a technology producer, educational institutions have an important role in providing knowledge for the community of coconut farmers with the task of higher education which is included in the tri dharma of higher education namely giving to the community

a) Training for coconut farmers who are involved in coconut agribusiness

In everyday life, almost all parts of the coconut plant are used for various purposes. This multi-benefit of coconut plants is still not fully utilized, namely at the roots, stems, leaves, flowers, and fruit. Efforts to develop the coconut agribusiness institution in Sulawesi in the North in the six elements involved, which became the first program of training for coconut farmers involved in coconut agribusiness, among others, needs to be developed again for ongoing training for the coconut farming community in this case in the business unit processing results for the information needs of the community of coconut farmers in North Sulawesi.

b) Provision of experts in running a coconut agribusiness business unit

The development of a coconut-based industry has good prospects. Indonesia as the largest coconut producer in the world has become a business venue from the procurement of production facilities to the diversification of coconut products and their supporting activities, such as finance, transportation, and trade. Efforts to develop a coconut agribusiness institution in North Sulawesi in the six elements involved in the program; providing experts in running the coconut agribusiness business unit carried out by the relevant institutions are collaborating with experts from academia in providing experts for the development of coconut processing for the benefit of the coconut farmers in North Sulawesi.

c. Assistance in each coconut agribusiness business unit

One of the potential and challenges for sustainable plantation development is limited research and development (R\&D) for the diversification of processed coconut products. The direction of the development of coconut agribusiness development is directed at improving the skills, professionalism, and competence of HR (Rukmana \& Yudirachman, 2016). Efforts to develop a coconut agribusiness institution in North Sulawesi in the six elements involved in the program; assistance in each coconut agribusiness business unit, carried out by the relevant institutions is to establish target villages so that assistance to coconut farmers can continue to be carried out for the development of coconut processing for the benefit of coconut farmers in North Sulawesi.

Paendong, S. M. P., Antara, M., Susrusa, K. B., \& Suamba, I. K. (2020). Institutional development of coconut agribusiness in North Sulawesi Province. International Journal of Life Sciences, 4(1), 8-18. https://doi.org/10.29332/ijls.v4n1.385 


\section{Conclusion}

Based on the results of the study identified several institutions that play a role in coconut agribusiness in North Sulawesi, namely: farmer groups, transportation businesses, universities, banks, cooperatives, field extension workers, collectors, middlemen, industries, wholesalers, village regulations, which is in coconut agribusiness in North Sulawesi. The role of each of these institutions is still weak because the existing institutions are still running independently and institutional involvement is still very minimal. The model of institutional strategy for developing coconut agribusiness in North Sulawesi, namely: Optimize the development of institutional functions as a vehicle for cooperation, a vehicle for education and channeling the aspirations of farmers; Increasing coconut farming processing business; Increasing the role of the community in all sectors of coconut agribusiness; Increase business players in developing coconut agribusiness; Increasing the synergy of institutional functions: Increasing the role of educational institutions in developing coconut agribusiness.

\section{Suggestion}

Based on the conclusions outlined, it can be suggested to stakeholders that; Coordination still needs to be maximized, thus affecting the actions of farmers, which will have an impact on people's welfare; Optimize the role of higher education institutions (academics) which are really needed from coconut farmers in North Sulawesi.

\section{Acknowledgments}

We are grateful to two anonymous reviewers for their valuable comments on the earlier version of this paper. 


\section{References}

Anantanyu, S. (2011). Kelembagaan petani: peran dan strategi pengembangan kapasitasnya. Jurnal Sepa, 7(2), 102-109.

Damanik, S. (2015). Strategi pengembangan agribisnis kelapa (Cocos nucifera) untuk meningkatkan pendapatan petani di Kabupaten Indragiri Hilir, Riau. Perspektif, 6(2), 94-104. http://dx.doi.org/10.21082/p.v6n2.2007.\%25p

Ginaya, G., Sudarmini, N. M., \& Damayanti, I. K. W. (2019). Tri hita karana and sad kertih values in Belimbing rural tourism development. International Journal of Social Sciences and Humanities,3(2), 10-23. https://doi.org/10.29332/ijssh.v3n2.282

Indraningsih, K. S. (2016). Faktor-faktor yang memengaruhi kinerja usahatani petani sebagai representasi strategi penyuluhan pertanian berkelanjutan di lahan marjinal.Jurnal Agro Ekonomi,31(1), 71-95. http://dx.doi.org/10.21082/jae.v31n1.2013.71-95

Krisnamurthi, B., Pambudi, R., \& Dabukke, F. B. M. (2010). Refleksi Agribisnis. 65 Tahun Profesor Bungaran Saragih.

Mujahidin, A. M. (2014). Panduan Penelitian Praktis untuk Menyusun Skripsi, Tesis dan Disertasi.

Pakpahan A. (2012). Kerangka Analitik untuk Penelitian Rekayasa Sosial: Perspektif Ekonomi Institusi. Prosiding Patanas: Evolusi Kelembagaan Pedesaan di Tengah Perkembangan Teknologi Pertanian. Pusat Penelitian Agro Ekonomi. Bogor.

Parraga, W. E. R., Parraga, M. A. C., Salazar, M. J. V., \& Albear, J. J. H. (2017). Reusing the coconut clay (brick) as construction material. International Research Journal of Engineering, IT \& Scientific Research, 3(4), 102109.

Rachbini, D. J. (2002). Ekonomi Politik Paradikma dan Teori Pilihan Publik, Jakarta. Ghalia Indonesia.

Rukmana, R., \& Yudirachman, H. (2016). Untung Berlipat dari Budi Daya Kelapa.

Saragih, B. (2010). Refleksi Agribisnis. Penerbit: Yudistira. Bogor.

Schmid, A. A. (1987). Property, power, and public choice: an inquiry into law and economics. A. Allan Schmid.

Uphoff, N. T. (1989). Approaches to community participation in agriculture and rural development. Economic Development Institute of the World Bank.

Paendong, S. M. P., Antara, M., Susrusa, K. B., \& Suamba, I. K. (2020). Institutional development of coconut agribusiness in North Sulawesi Province. International Journal of Life Sciences, 4(1), 8-18. https://doi.org/10.29332/ijls.v4n1.385 


\section{Biography of Authors}

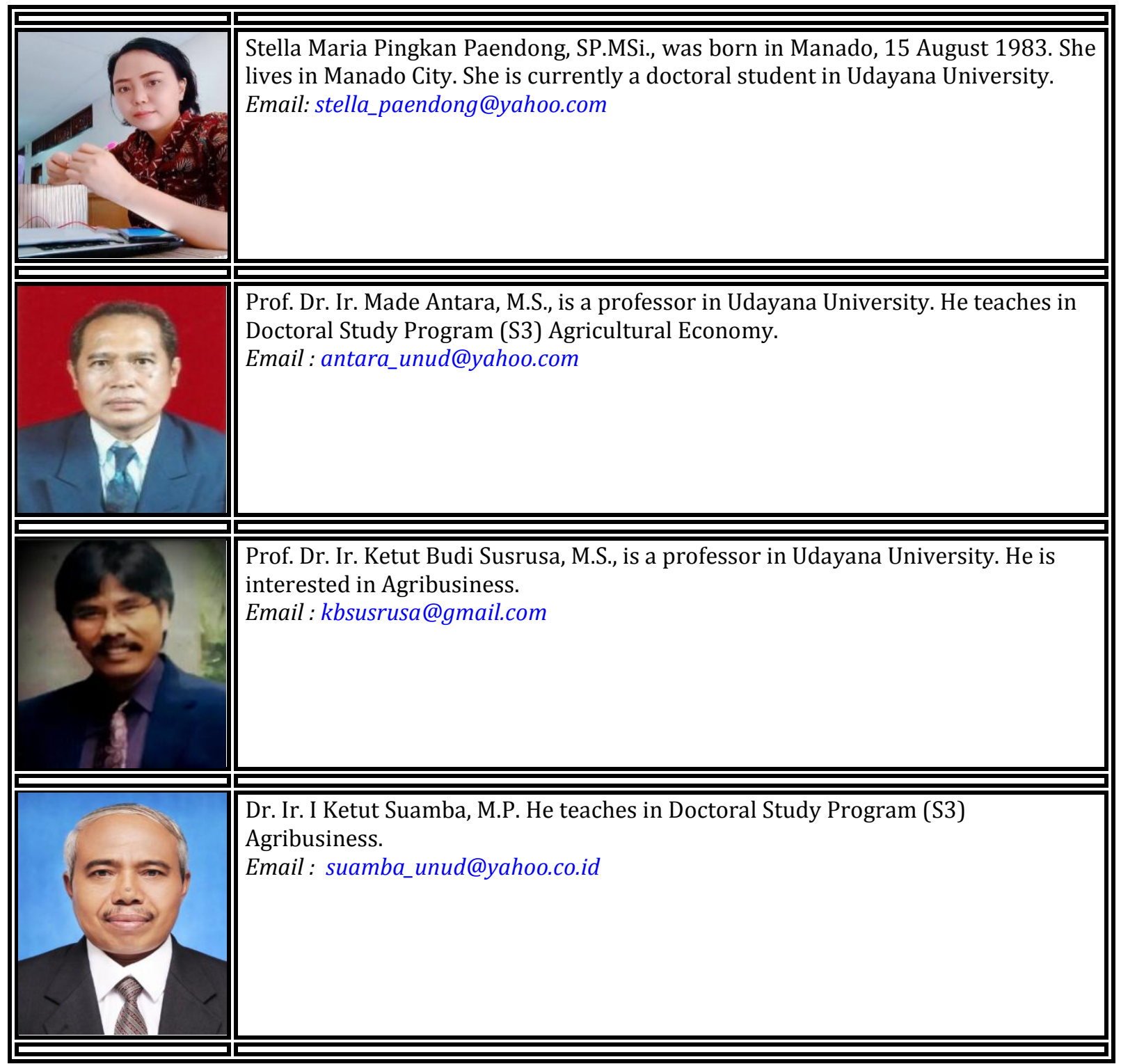

